\title{
Eosinophils Utilize Multiple Chemokine Receptors for Chemotaxis to the Parasitic Nematode Strongyloides stercoralis
}

\author{
Louis H. Stein $^{a}$ Kevin M. Redding ${ }^{a}$ James J. Lee ${ }^{c}$ Thomas J. Nolan ${ }^{b}$ \\ Gerhard A. Schad $^{b}$ James B. Lok ${ }^{b}$ David Abraham ${ }^{a}$

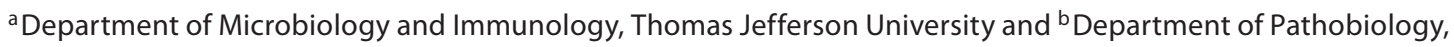 \\ University of Pennsylvania, Philadelphia, Pa., ' Department of Biochemistry and Molecular Biology, \\ Mayo Clinic Scottsdale, Scottsdale, Ariz., USA
}

\section{Key Words}

Eosinophil $\cdot$ Chemotaxis $\cdot$ Strongyloides stercoralis $\cdot$ CCR3 $\cdot$

CXCR4 $\cdot$ CXCR2

\begin{abstract}
Protective innate immunity to the nematode Strongyloides stercoralis requires eosinophils in the parasite killing process. Experiments were performed to determine if an extract of $S$. stercoralis would trigger eosinophil chemotaxis, and to then compare the chemotactic migration response, including second messenger signals and receptors, to those mechanisms triggered by host chemoattractants. Eosinophils undergo both chemotaxis and chemokinesis to soluble parasite extract in transwell plates. Pretreatment of eosinophils with pertussis toxin, a $\mathrm{G}$ protein-coupled receptor inhibitor, inhibited migration of the eosinophils to the parasite extract. Likewise, blocking PI3K, tyrosine kinase, p38 and p44/42 inhibited eosinophil chemotaxis to parasite extract. Furthermore, CCR3, CXCR4 or CXCR2 antagonists significantly inhibited eosinophil chemotaxis to the parasite extract. Molecular weight fractionation of parasite extract revealed that molecules attracting eosinophils were present in several fractions, with molecules greater than $30 \mathrm{kDa}$ being the most potent. Treating the extract with proteinase K or chitinase significantly inhibited its ability to induce chemotaxis,
\end{abstract}

thereby demonstrating that the chemoattractants were both protein and chitin. Therefore, chemoattractants derived from parasites and host species stimulate similar receptors and second messenger signals to induce eosinophil chemotaxis. Parasite extract stimulates multiple receptors on the eosinophil surface, which ensures a robust innate immune response to the parasite.

Copyright $\odot 2009$ S. Karger AG, Basel

\section{Introduction}

Chemokines are derived from heterogeneous sources and direct leukocytes to sites of inflammation. Over 50 chemokines have been identified in humans and are characterized as small proteins ranging in size from 8 to $10 \mathrm{kDa}[1,2]$. Eosinophilia is strongly linked with parasitic infections $[3,4]$ and eosinophils have been identified as effector-killing cells controlling various nematodes [5, 6] including Strongyloides stercoralis [7]. In humans, dermal expression of both eotaxin/CCL11 and RANTES/ CCL5 correlates with the numbers of dermal eosinophils associated with the early phases of Onchocerca volvulus infection, suggesting the importance of host expressed chemokines in directing this response $[8,9]$. The importance of chemokines is underscored by the fact that eo-

\section{KARGER}

(C) 2009 S. Karger AG, Basel

Fax +4161306 1234

E-Mail karger@karger.ch

www.karger.com
Accessible online at: www.karger.com/jin
Dr. David Abraham

Department of Microbiology and Immunology

Thomas Jefferson University

233 South 10th Street, Philadelphia, PA 19107 (USA)

Tel. +1 215503 8917, Fax +1 215923 9248, E-Mail david.abraham@jefferson.edu 
taxin-1/CCL11 knockout mice exhibit decreased eosinophil tissue influx and an inability to clear infection with Brugia malayi microfilariae [10]. However, eosinophil migration to the intestine is decreased but not absent in eotaxin/CCL11 knockout mice infected with Trichinella spiralis and Trichuris muris [11]. Production of chemoattractant molecules by the parasites could explain the presence of eosinophils in the infected tissues of mice with attenuated chemokine expression.

Numerous studies have demonstrated that various parasites synthesize molecules with the capacity to attract leukocytes, and products triggering eosinophil chemotaxis have been isolated from parasitic nematodes [12, 13]. Compared to the relatively uniform structure of mammalian chemokines, chemoat tractants derived from parasites are a more biochemically diverse collection of molecules. These chemoattractants range in size from 5 to $40 \mathrm{kDa}[14,15]$, and have been identified as both proteins and nonproteins [14, 16-18].

Eosinophil migration can be stimulated in either a chemokinetic (random) or chemotactic (directed) fashion after binding their ligands. Chemotaxis typically requires the stimulation of 7 transmembrane pertussis toxin (PTX)-sensitive $G$ protein-coupled chemokine receptors (GPCR) [19-21]. Different chemokine receptors are expressed in eosinophils associated with particular disease states. CCR3 has been described as the dominant receptor in eosinophils in models of allergy [22-25]. CXCR2 is expressed in human eosinophils after priming with IL-5 [23] and is a receptor for B. malay-derived chemoattractant molecules [16]. At sites of inflammation, eosinophil CXCR4 expression is increased, while CCR3 is decreased $[24,26]$.

Once stimulated by its ligand, a GPCR must induce second messenger signals to provoke a chemotactic response. Stimulation of chemokine receptors induces the dissociation of a heterotrimeric $G$ protein into $G \alpha$ and $\mathrm{G} \beta \gamma$ subunits, which in turn regulate multiple second messenger signals [27]. Subsequent second messenger pathways include tyrosine kinases [28] and phosphoinositide 3-kinase (PI3K). These products can stimulate other second messengers including protein kinase $\mathrm{B}$, protein kinase $C$ and GTP-binding Rac. Mitogen-activated protein kinases (MAPK) integrate these intracellular messages [29]. Of the 6 MAPK families, p38 and p44/42 (ERK1/ERK2) factor significantly in eotaxin/CCL11 stimulation of eosinophils [30, 31]. Eotaxin/CCL11-triggered eosinophil chemotaxis is mediated through both p38 and p44 [30], whilst mast cell chymase [32], SDF-1 $\alpha /$ CXCL12 [33] or fMLP [34] do not utilize p38 to stimulate eosinophil migration. Furthermore, SDF-1 $\alpha /$ CXCL12 utilizes p44/42 for intracellular signaling [33].

Eosinophils are involved in the innate immune response to S. stercoralis [7] and migration to sites of nematode infection persists even with attenuated host chemokines [11]. Experiments were performed to determine if a soluble extract from $S$. stercoralis triggers eosinophil chemotaxis and to then compare the migration response, including second messenger signals and receptors, to those mechanisms triggered by host chemoattractants.

\section{Materials and Methods}

\section{Reagents}

Recombinant mouse IL-5 was purchased from BD Biosciences (San Jose, Calif. USA). The chemokines mouse eotaxin/CCL11 and SDF- $1 \alpha \beta / C X C L 12$ were purchased from Sigma Chemical Co. (St. Louis, Mo., USA.) and MIP-2/CXCL2 was purchased from PeproTech (RockyHill, N.J., USA). N-[2-hydroxyethyl]piperazine$N$-[2-ethanesulfonic acid] (HEPES), piperazine- $N, N$-bis[2-ethane-sulfonic acid] (PIPES), ethylenediaminetetraacetic acid (EDTA), ethylene glycol-bis[2-aminoethyl ether]tetraacetic acid (EGTA), Percoll and glucose were purchased from Sigma Chemical Co. Fetal bovine serum (FBS), Hank's balanced salt solution, and Dulbecco's phosphate-buffered saline (PBS) were purchased from Mediatech (Herndon, Va., USA). Anti-B220 and Thy1.2 antibody-conjugated magnetic beads were purchased from Miltenyi Biotech (Auburn, Calif., USA). Bordetella PTX and SB202190, a p38 inhibitor, were purchased from Calbiochem Inc. (San Diego, Calif., USA) Wortmannin, a PI3K inhibitor, and herbimycin A, a tyrosine kinase inhibitor, were purchased from Sigma Chemical Co. The MEK kinase inhibitor, PD98059, was purchased from Biosource International Inc., (Camarillo, Calif., USA). SB222200, a neurokinin (NK)3 Receptor antagonist, was procured from Tocris Bioscience (Ellisville, Mo., USA). SB328437, a CCR3 antagonist, and SB225002, a CXCR2 antagonist, were purchased from Calbiochem. The CXCR4 antagonist, AMD 3100, was purchased from Sigma Chemical Co. The digestive enzymes, proteinase K from Tritirachium album and chitinase from Serratia marcescens were purchased from Sigma Chemical Co.

\section{Animals}

IL-5 transgenic mice of the NJ.1638 line [35] were bred at the Thomas Jefferson University Laboratory Animal Sciences Facility. Experiments were conducted using eosinophils recovered from mice at 4-6 months of age. Mice were housed at the Thomas Jefferson University Laboratory Animal Sciences Facility in microisolator boxes with ambient temperature and light continuously controlled.

\section{Parasites}

Third-stage infective larvae (L3) were isolated from the stool of laboratory dogs infected with S. stercoralis according to previously described methods [36]. Larvae were recovered from charcoal cultures and washed in a sterile mixture of NCTC-135 and IMDM (1:1 vol/vol), which was supplemented with $100 \mathrm{U} / \mathrm{ml}$ pen- 
icillin (Mediatech), $0.1 \mathrm{mg} / \mathrm{ml}$ streptomycin, $0.1 \mathrm{mg} / \mathrm{ml}$ gentamycin (Gibco Lifesciences, Rockville, Md., USA) and $0.25 \mathrm{mg} / \mathrm{ml}$ Levaquin (Ortho-McNeil, Raritan, N.J., USA).

Preparation of S. stercoralis Protein Extract

S. stercoralis L3 were washed using an agar cleaning method. Worms were mixed in a 1:1 mixture of PBS and 2.0\% agarose (Sigma Chemical Co.). The agarose mixture was allowed to solidify on the bottom of a Petri dish and then covered with PBS containing the previously described antibiotics. The worms that migrate into the PBS were collected and killed by 2 successive freeze-thaw cycles between room temperature and $-20^{\circ} \mathrm{C}$. To suppress proteolysis, a protease inhibitor cocktail (product number P2714; Sigma Chemical Co.) was added to the mixture. Worms were homogenized, sonicated and then incubated overnight with $\mathrm{PBS}$ at $4^{\circ} \mathrm{C}$ in a rotating shaker. The PBS soluble supernatant was removed, filter sterilized $(0.2 \mu \mathrm{m}$ membrane) and stored at $-80^{\circ} \mathrm{C}$. Endotoxin levels in the extract were determined using a Limulus amebocyte lysate test (Cambrex, Charles City, Iowa, USA) and lipopolysaccharide (LPS) was removed by pre-incubation of the parasite extract in polymyxin B (Sigma Chemical Co.).

\section{Isolation of Spleen Eosinophils from IL-5 Transgenic Mice}

IL-5 transgenic mice were anesthetized with isoflurane (Webster Veterinary, Sterling, Mass., USA) and killed by exsanguination. The spleen was aseptically removed and then homogenized in $2.0 \% \mathrm{FBS} / \mathrm{PBS}$ using a sterile glass homogenizer. The homogenate was run through a $70-\mu \mathrm{m}$ nylon cell strainer and layered onto a Percoll E column (Sigma). After centrifugation, the buffy coat was removed and resuspended in $2 \% \mathrm{FBS} / \mathrm{PBS}$. The resulting suspension was recentrifuged and hypotonic red blood cell lysis was performed.

To remove contaminating cells, magnetic cell sorting columns (Miltenyi Biotec) were used. The cells were incubated with manufacturer-supplied antibodies coupled to microbeads (anti-B220, to remove B cells; anti-Thy1.2, to remove T cells; $10 \mu$ l of antibody/ $10^{7}$ cells) at $4^{\circ} \mathrm{C}$ for $45 \mathrm{~min}$. The samples were then washed twice in $2 \% \mathrm{FBS} / \mathrm{PBS}$. The pellet was resuspended in FBS/PBS and applied to the magnetic cell sorting column, and cells were collected in the effluent. The cells were resuspended in RPMI with no additives. The cells were then stained with erythrocin B to ensure $>90 \%$ viability, and DiffQuik (Baxter Healthcare, Miami, Fla., USA) to ensure $>90 \%$ purity, with the contaminating cells consisting of $1-2 \%$ neutrophils, $2-4 \%$ macrophages and $1-2 \%$ lymphocytes.

\section{Eosinophil Migration Assay}

Eosinophil migration in response to the PBS-soluble S. stercoralis extract was measured using Corning Costar 6.5- $\mathrm{mm}$ transwell plates with $3.0-\mu \mathrm{m}$ pore polycarbonate membranes. Membranes and wells were preincubated with $100 \mu \mathrm{l} 2 \% \mathrm{FBS}$ for $1 \mathrm{~h}$ at room temperature. Eosinophils from the spleens of IL-5 transgenic mice ( $\geq 90 \%$ purity) suspended in RPMI $\left(100 \mu \mathrm{l} ; 1.0 \times 10^{4}\right.$ cells/ $\mu \mathrm{l})$ and IL-5 in $2 \%$ FBS $(50 \mu \mathrm{l} ; 30 \mathrm{ng} / \mathrm{ml})[37,38]$ were added to the upper wells. S. stercoralis extract $(200 \mu \mathrm{l} ; 0.001-1.00 \mu \mathrm{g} / \mu \mathrm{l})$, negative controls, FBS $(200 \mu \mathrm{l}, 2 \%)$, positive controls, mouse eotaxin/CCL11 (80 ng/ml), SDF-1 $\alpha \beta / C X C L 12$ (400 ng/ml) or MIP2/CXCL2 $(50 \mathrm{ng} / \mathrm{ml})$ were added to lower wells. The assay was then incubated for $90 \mathrm{~min}$ at $37^{\circ} \mathrm{C}$. Chemoattractant doses were chosen so that at baseline, statistically equivalent numbers of untreated eosinophils migrated in each series of experiments.

Following incubation, the upper membranes were removed and cell-containing media in the lower wells was pipetted into microcentrifuge tubes. PIPES buffer $(250 \mu \mathrm{l})$ was added to each lower well to collect any remaining cells. Samples were centrifuged for $5 \mathrm{~min}$ at $4^{\circ} \mathrm{C}$ and the cells counted using a hemocytometer. The effect of a given chemoattractant was calculated as the fold increase in eosinophil migration to the chemoattractant as compared to $2 \%$ FBS. The effect of second messenger inhibitors and receptor antagonists were determined by calculating the number of treated eosinophils migrating as a percent of the number of untreated eosinophils migrating to the same stimulus minus background migration to $2 \% \mathrm{FBS}$.

\section{Zigmond-Hirsch Checkerboard Assay}

To distinguish between eosinophil chemotaxis and chemokinesis, checkerboard assays were performed as described previously [39]. Serial doses of extract $(0.01-1.0 \mathrm{mg} / \mathrm{ml}$ total protein) were added to the top and bottom wells of transwell plates. The effect of different concentrations of extract in the top and bottom well was measured as the ratio of the number of eosinophils migrating in the presence of extract to the number of eosinophils migrating with only $2 \%$ FBS.

The Effect of Second-Messenger Signal Inhibitors on

Eosinophil Migration

To examine the second messenger pathways involved in mediating eosinophil migration in response to extract, inhibitors of various signaling molecules involved in eosinophil chemotaxis were used. Eosinophils were pretreated with PTX (10-1,000 ng/ $\mathrm{ml}$ ) for $1 \mathrm{~h}$ at $37^{\circ} \mathrm{C}$ and the resulting chemotaxis to eotaxin/CCL11 or S. stercoralis was measured to determine if migration was triggered through a $\mathrm{G} \alpha_{\mathrm{i}} \mathrm{GPCR}$. Eosinophils were preincubated for $1 \mathrm{~h}$ in the presence of the PI3K inhibitor, wortmannin $\left(1 \times 10^{-9}\right.$ to $\left.1 \times 10^{-7} \mathrm{M}\right)$, the tyrosine kinase inhibitor, herbimycin $\mathrm{A}(1 \times$ $10^{-8}$ to $\left.1 \times 10^{-6} \mathrm{M}\right)$, the p38 inhibitor, SB202190 $\left(1 \times 10^{-7}\right.$ to $1 \times$ $\left.10^{-5} \mathrm{M}\right)$ or the $\mathrm{p} 44 / 42$ inhibitor PD98059 $\left(1 \times 10^{-9}\right.$ to $\left.1 \times 10^{-7} \mathrm{M}\right)$. After pretreatment, eosinophils were placed in the top well of the transwell pate and the eosinophil migration assay to eotaxin/ CCL11, SDF-1 $\alpha /$ CXCL12 and the S. stercoralis extract was determined as described above.

\section{Effect of Chemokine Receptor Antagonists on Eosinophil \\ Migration}

Eosinophils were pretreated with chemokine receptor antagonists to determine the chemokine receptors stimulated by the $S$. stercoralis extract. Cells were pretreated with varying doses of the CCR3 antagonist, SB328437 $\left(1 \times 10^{-7}\right.$ to $\left.1 \times 10^{-5} \mathrm{M}\right)$, the CXCR4 antagonist, $\mathrm{AMD} 3100\left(4 \times 10^{-11}\right.$ to $\left.4 \times 10^{-8} \mathrm{M}\right)$, and the CXCR2 antagonist, SB225002 $\left(1 \times 10^{-7}\right.$ to $\left.1 \times 10^{-5} \mathrm{M}\right)$, for $1 \mathrm{~h}$ at $37^{\circ} \mathrm{C}$. Eosinophils were placed in the top well of the transwell plate and migration to the $S$. stercoralis extract and positive as well as negative controls was calculated as described above. Migration to eotaxin/CCL11 (80 ng/ml) was used as a positive control for the CCR3 antagonist, and as the negative control for all other antagonists. Eosinophil migration to SDF- $1 \alpha \beta /$ CXCL12 $(400 \mathrm{ng} / \mathrm{ml})$ was a positive control for the CXCR4 antagonist and MIP-2/CXCL2 $(50 \mathrm{ng} / \mathrm{ml})$ for the CXCR2 antagonist. 
Table 1. Chemotactic and chemokinetic activity induced by $S$. stercoralis extract (S. stercoralis extract was added to the upper and lower wells of Costar transwell plates)

\begin{tabular}{lllll}
\hline \multirow{2}{*}{ Lower wells } & \multicolumn{4}{l}{ Upper Wells } \\
\cline { 2 - 5 } & Control & 0.01 & 0.1 & 1.0 \\
\hline Control & 1 & $1.2 \pm 0.1$ & $1.8 \pm 0.4$ & $3.6 \pm 1.0$ \\
0.01 & $1.4 \pm 1.0$ & $1.5 \pm 0.2$ & $3.1 \pm 1.0$ & $3.1 \pm 0.5$ \\
0.1 & $1.6 \pm 0.3$ & $2.7 \pm 1.8$ & $1.9 \pm 0.4$ & $5.0 \pm 1.3$ \\
1.0 & $6.4 \pm 1.6$ & $3.5 \pm 1.0$ & $5.2 \pm 1.3$ & $3.9 \pm 0.7$ \\
\hline
\end{tabular}

In addition to the extract, $1 \times 10^{6}$ eosinophils and $30 \mathrm{ng} / \mathrm{ml}$ IL-5 were added to the upper chambers. Eosinophil chemotaxis (directed migration) was evaluated with increasing concentration of the S. stercoralis extract, represented in the columns. Chemokinesis (nondirected migration), represented on the diagonal, was measured by equivalent doses of the $S$. stercoralis extract in the top and bottom wells. Numbers presented are mean fold increase in eosinophil migration compared to the control across 4 experiments \pm standard error of the mean.

To confirm that any reduction in migration is due to specific receptor inhibition by the antagonist, we tested the effect of a chemically similar antagonist to a receptor, which was determined to have a negligible effect on eosinophil migration [40]. To do this, we measured the effect of eosinophil migration to eotaxin/CCL11 and the extract after incubation with an NK3 antagonist, SB222200 $\left(1 \times 10^{-5}\right.$ to $\left.1 \times 10^{-2} \mathrm{M}\right)$.

\section{Fractionation of the Extract according to Molecular Weight}

$S$. stercoralis extract was fractionated according to molecular weight by passing the extract through a sequence of centrifugal filters (Millipore, Bedford, Mass., USA) with different molecular weight cutoffs. The extract was first passed through a column with a $30-\mathrm{kDa}$ cutoff, the effluent was then passed through a 10 $\mathrm{kDa}$ filter, and the subsequent effluent was then passed through a $3-\mathrm{kDa}$ filter. This process yielded fractions containing molecules in the following ranges: $<3 \mathrm{kDa}, 3-10 \mathrm{kDa}, 10-30 \mathrm{kDa}$ and $>30 \mathrm{kDa}$. Concentration of each fraction was normalized to $1 \mathrm{mg} /$ $\mathrm{ml}$ of total protein.

\section{Biochemical Modification of the Extract}

Three treatments were used to characterize the biochemical constituents of the chemotactic component of the S. stercoralis extract. (1) Aliquots were boiled in a water bath for $10 \mathrm{~min}$ before testing in the chemotaxis assay. (2) The activity of the protein component was determined by treating the extract with $30 \mathrm{U} / \mathrm{mg}$ of proteinase $\mathrm{K}$, a nonspecific proteinase, for $2 \mathrm{~h}$ at $37^{\circ} \mathrm{C}$ followed by enzyme inactivation by boiling for $10 \mathrm{~min}$. (3) To determine if chitin from $S$. stercoralis was required for chemotaxis, extract was treated with $100 \mu \mathrm{l}$ of $5 \times 10^{-3} \mathrm{U} / \mathrm{ml}$ chitinase for $2 \mathrm{~h}$ at $37^{\circ} \mathrm{C}$.

\section{Statistics}

Statistical analysis of the data was performed using multivariate general linear hypothesis multifactorial ANOVA with Systat version 11 software (Systat, Evanston, Ill. USA). Fisher's least significant difference test was performed for post hoc analyses. Probability values of $p<0.05$ were considered significant. Doseresponse experiments demonstrating migration in response to the extract were calculated as the ratio of cells migrating to chemoattractant to the number of cells migrating to 2\% FBS control [fold increase in migration $=$ number of eosinophils migrating to stimuli $\times$ (number of eosinophils migrating to $2 \% \mathrm{FBS})^{-1}$ ]. The effect of various intracellular inhibitors and receptor antagonists was evaluated by measuring the percent inhibition when compared to untreated cells. Inhibition assays are presented as the percent decrease in migration of treated eosinophils to the chemoattractant minus the migration of treated eosinophils to $2 \%$ FBS compared to the number of untreated eosinophils to chemoattractant minus the number of untreated eosinophils to $2 \%$ FBS. Percent inhibition $=100 \times[$ (number of untreated eosinophils migrating to chemoattractant - number of untreated eosinophils migrating to control) - (number of treated eosinophils migrating to chemoattractant - number of treated eosinophils migrating to control)] $\times$ (number of untreated eosinophils migrating to chemoattractant - number of untreated eosinophils migrating to control) $)^{-1}$. Experiments were repeated 4-6 times and the data presented are means \pm standard error of the mean.

\section{Results}

\section{Soluble Parasite Extract Induces Eosinophil Chemotaxis}

Eosinophils exhibited a $6.4 \pm 1.6$ fold increase in migration above control when $1 \mathrm{mg} / \mathrm{ml}$ of $S$. stercoralis extract was used in the transwell analysis. This corresponded to a migration of $27 \pm 5 \times 10^{3}$ cells in response to the parasite extract as compared to $5 \pm 2 \times 10^{3}$ cells in the control wells. Eosinophil migration was not significantly greater than in the control when concentrations less than $1 \mathrm{mg} / \mathrm{ml}$ of extract were tested (table 1). Zigmond-Hirsch checkerboard analysis was performed to determine if the parasite extract induced chemotactic (directed toward a chemical gradient) or chemokinetic (random) migration. Serial dilutions of extract were added to the top and bottom wells of transwell plates. Eosinophil chemotaxis was determined as increasing migration in response to increasing dose of extract in the lower wells in the transwell plate. Chemokinetic effects were measured when there were equal doses of extract in top and bottom wells. The maximal chemokinetic effect was observed with $21 \pm$ $10 \times 10^{3}$ migrating cells with $1 \mathrm{mg} / \mathrm{ml}$ of extract in the top and bottom wells, corresponding to $3.9 \pm 0.7$ fold increase in migration over control (table 1). Cells used in the chemotaxis studies were greater than $90 \%$ pure eosinophils. The cells that migrated through the membranes were stained and differentials performed to deter- 


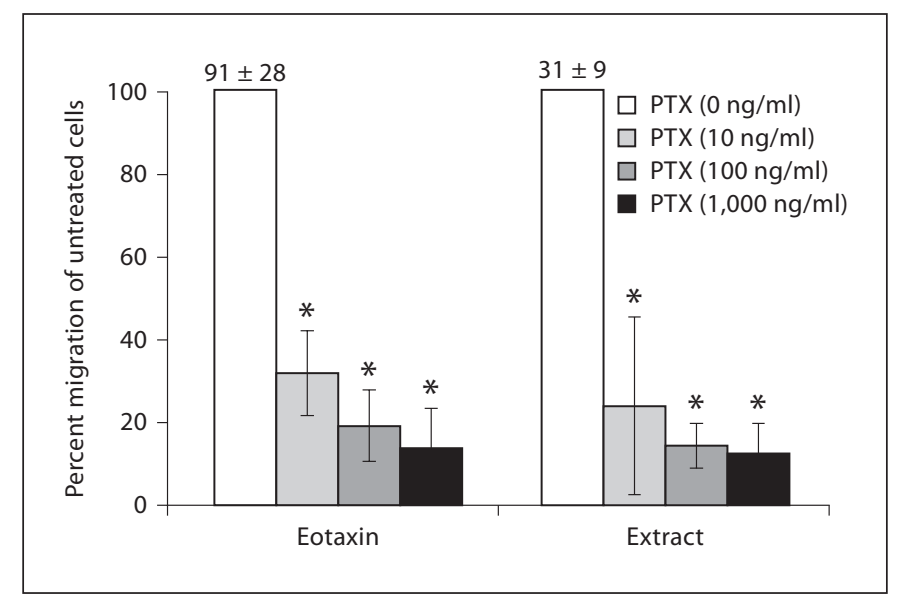

Fig. 1. S. stercoralis extract stimulates eosinophil migration through $\mathrm{G} \alpha_{\mathrm{i}}$ GPCR. $1 \times 10^{6}$ eosinophils were added with $30 \mathrm{ng} /$ $\mathrm{ml} \mathrm{IL}-5$ to the upper chambers of a transwell plate. Chemotaxis was stimulated with either eotaxin/CCL11 $(80 \mathrm{ng} / \mathrm{ml})$ or $S$. stercoralis extract $(1 \mathrm{mg} / \mathrm{ml})$ in the lower wells. Eosinophils were preincubated with increasing doses of Bordetella PTX (0-1,000 ng/ $\mathrm{ml})$. Data are presented as percentage of migration in relation to untreated control (100\%). Bars represent the mean percentage over 4 experiments \pm standard error of the mean. Numbers above control bars indicate the raw number of untreated migrated cells (arithmetic mean \pm standard error of the mean $\times 10^{3}$ migrated cells). ${ }^{*} \mathrm{p}<0.05$.

mine if the cells that underwent chemotaxis were eosinophils or the contaminating cells. It was determined that $100 \%$ of the cells that migrated through the membranes in response to the parasite extract were eosinophils. Therefore, S. stercoralis extract stimulates eosinophil chemotaxis with some effect on chemokinetic activity.

Using a Limulus amebocyte lysate test, $0.1 \mathrm{ng} / \mathrm{ml}$ of LPS was present in the S. stercoralis extract. However, no chemotaxis of eosinophils was observed in response to LPS at concentrations one $\log _{10}$ above and below that present in the $S$. stercoralis extract. Furthermore, pretreating the parasite extract with polymyxin B to block the effects of active lipid A component of LPS did not diminish eosinophil migration to the extract (data not shown). Thus, the observed eosinophil migration is due to the effect of the parasite extract and not attributable to LPS.

\section{S. stercoralis Extract Stimulates Eosinophil}

Migration through $G \alpha_{i} G P C R$

Eosinophils were preincubated with increasing doses of the $\mathrm{G} \alpha_{\mathrm{i}}$ inhibitor, PTX, to determine if the S. stercoralis extract uses the $\mathrm{G} \alpha_{\mathrm{i}}$ GPCR to generate eosinophil mi- gration. The effect of PTX was calculated as the percent reduction in eosinophil migration of treated cells compared to untreated cells. Pretreatment with PTX significantly inhibited eosinophil chemotaxis in a dose-response fashion to both the parasite extract and the control eotaxin/CCL11. The highest dose of PTX tested inhibited chemotaxis to eotaxin/CCL11 by $86 \%$ and to extract by $88 \%$ (fig. 1). Therefore, parasite extract activates eosinophil chemotaxis by stimulating 1 or more $\mathrm{G} \alpha_{\mathrm{i}}$-coupled receptors.

\section{S. stercoralis Extract Signals Eosinophil Chemotaxis Using PI3K and Tyrosine Kinase as Second Messenger Signals}

To gain insight into the second messenger signals stimulated by the extract, eosinophils were pretreated with agents to block second messengers known to be important for eosinophil chemotaxis. Eosinophils were pretreated with the PI3K inhibitor, wortmannin, to determine the role of PI3K in extract-induced chemotaxis. All doses of wortmannin significantly inhibited eosinophil chemotaxis in response to the extract and to the controls eotaxin/CCL11 and SDF-1 $\alpha /$ CXCL12. At the maximum dose of wortmannin tested, baseline chemotaxis stimulated by eotaxin/CCL11 was inhibited by $95 \%$, baseline chemotaxis stimulated by SDF-1 $\alpha /$ CXCL12 was inhibited by $91 \%$ and the parasite extract by $95 \%$ (fig. $2 a$ ).

To determine whether the parasite extract-induced eosinophil chemotaxis utilized tyrosine kinases, eosinophils were pretreated with various doses of the nonspecific tyrosine kinase inhibitor herbimycin A. At all tested doses, herbimycin A significantly reduced eosinophil chemotaxis to the control eotaxin/CCL11 by approximately $71 \%$ and to SDF- $1 \alpha /$ CXCL12 by approximately $41 \%$. Herbimycin A also significantly inhibited chemotaxis in response to the parasite extract, inhibiting baseline migration by $48-70 \%$ in a dose-dependent fashion (fig. 2b). Therefore, eosinophils migrate to the S. stercoralis extract using both $\mathrm{PI} 3 \mathrm{~K}$ and tyrosine kinases.

\section{S. stercoralis Extract Utilizes p38 and p42/44 MAPK as Effector Signals}

The MAPK p38 and p42/44 are involved in the chemotaxis of many types of cells and each was examined for its ability to mediate eosinophil chemotaxis stimulated by the extract. p38 signaling was assessed by treating eosinophils with the p38 inhibitor, SB202190. Blocking p38 significantly inhibited eotaxin/CCL11-triggered eosinophil chemotaxis in a dose-response fashion, with a maximum of $96 \%$ inhibition of migration. Eosinophil migra- 


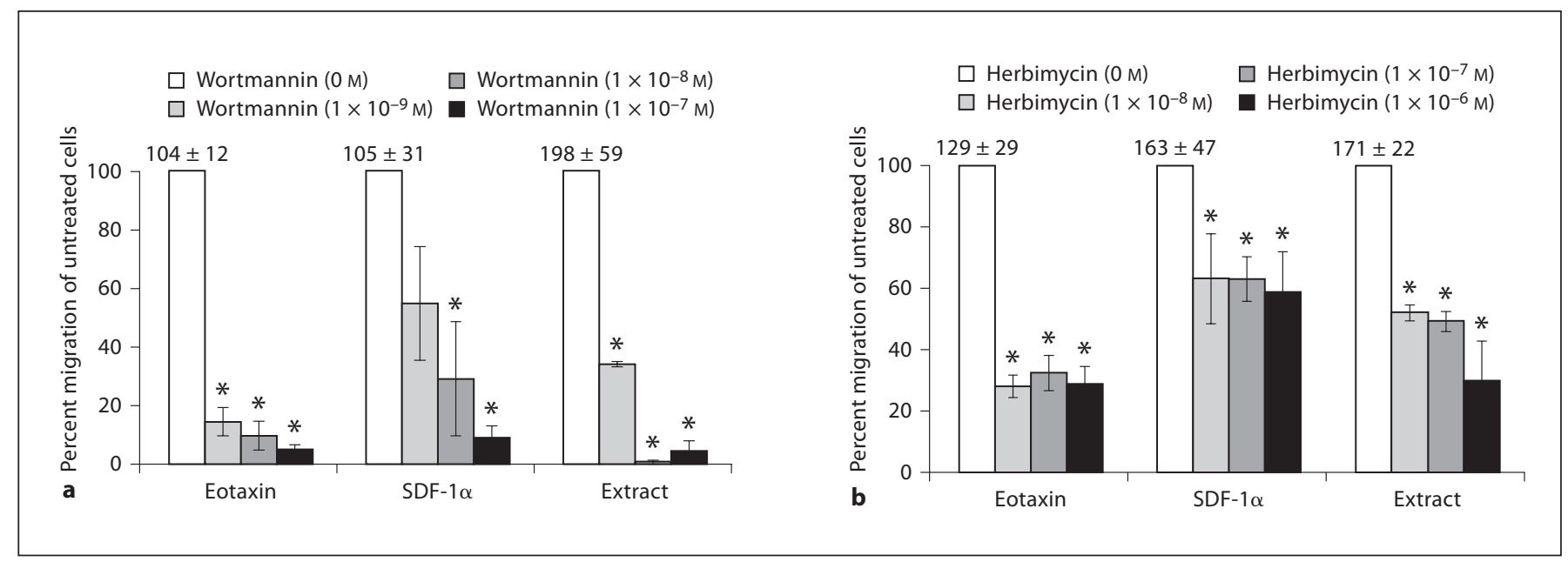

Fig. 2. S. stercoralis extract stimulates eosinophil chemotaxis using PI3K and tyrosine kinases. Eosinophils $\left(1 \times 10^{6}\right.$ cells $)$ were added with IL-5 (30 ng/ml) to the upper chambers of a transwell plate. Chemotaxis was stimulated by incubation with either eotaxin/CCL11 (80 ng/ml), SDF-1 $\alpha /$ CXCL12 (400 $\mu \mathrm{g} / \mathrm{ml})$, or S. stercoralis extract $(1 \mathrm{mg} / \mathrm{ml})$. a Eosinophils were pretreated with the PI3K inhibitor, wortmannin $\left(1 \times 10^{-9}\right.$ to $\left.1 \times 10^{-7} \mathrm{M}\right)$. b Eosinophils were pretreated with various doses of the nonspecific tyro- sine kinase inhibitor herbimycin $\mathrm{A}\left(1 \times 10^{-8}\right.$ to $\left.1 \times 10^{-6} \mathrm{M}\right)$. Data are presented as percentage of migration in relation to untreated control, represented as $100 \%$. Bars represent the mean percentage over 4-6 experiments \pm standard error of the mean. Numbers above control bars indicate the raw number of untreated migrated cells (arithmetic mean \pm standard error of the mean $\times 10^{3} \mathrm{mi}-$ grated cells). ${ }^{*} \mathrm{p}<0.05$.

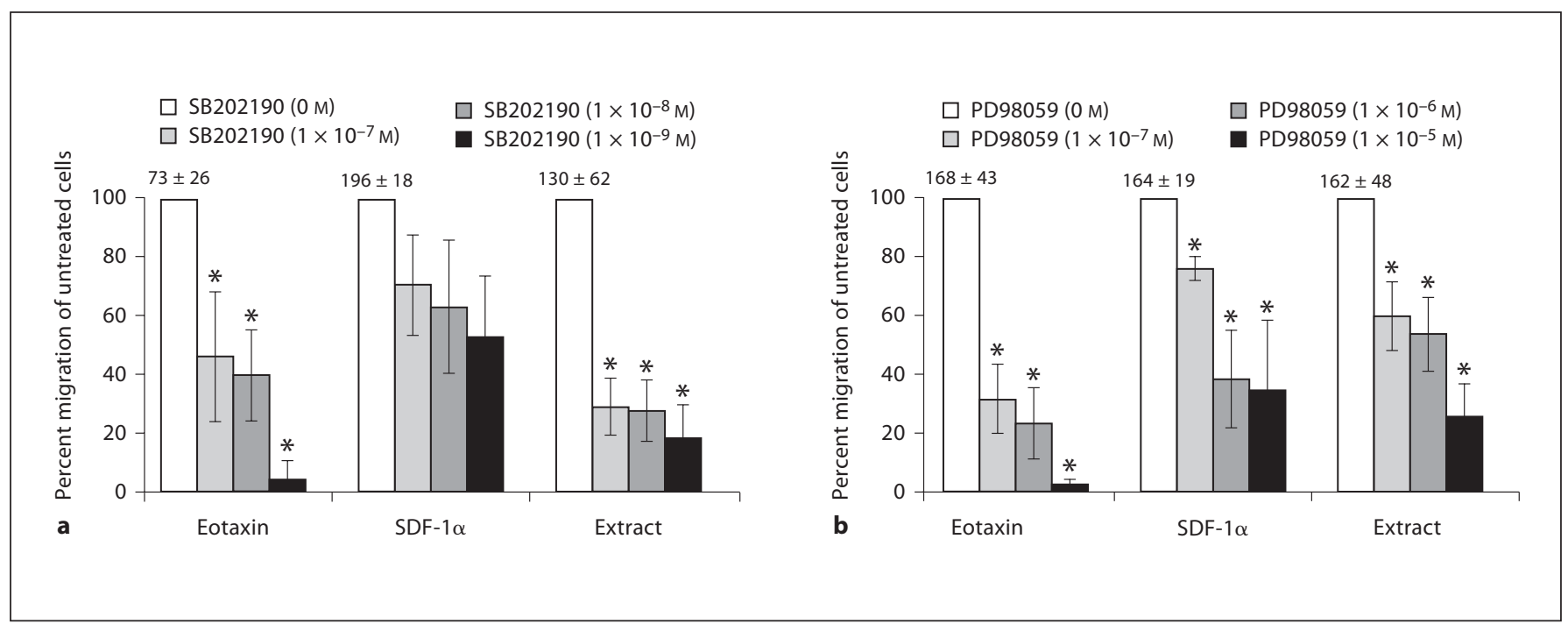

Fig. 3. Increasing doses of the p38 MAPK cascade inhibitor, SB202190, and the p42/44 MEK inhibitor, PD98059, inhibited eosinophil chemotaxis. Eosinophils $\left(1 \times 10^{6}\right.$ cells $)$ were added with IL-5 $(30 \mathrm{ng} / \mathrm{ml})$ to the upper chambers of a transwell plate. Chemotaxis was stimulated by incubation with either eotaxin/CCL11 (80 ng/ml), SDF-1 $\alpha /$ CXCL12 $(400 \mu \mathrm{g} / \mathrm{ml})$, or S. stercoralis extract (1 mg/ml). Blocking p38 with SB202190 (a) and blocking p42/44 with PD98059 (b) are shown. Data are presented as percentage of migration in relation to untreated control, represented as $100 \%$. Bars represent the mean percentage over 5-6 experiments \pm standard error of the mean. Numbers above control bars indicate the raw number of untreated migrated cells (arithmetic mean \pm standard error of the mean $\times 10^{3}$ migrated cells). ${ }^{*} \mathrm{p}<0.05$. 


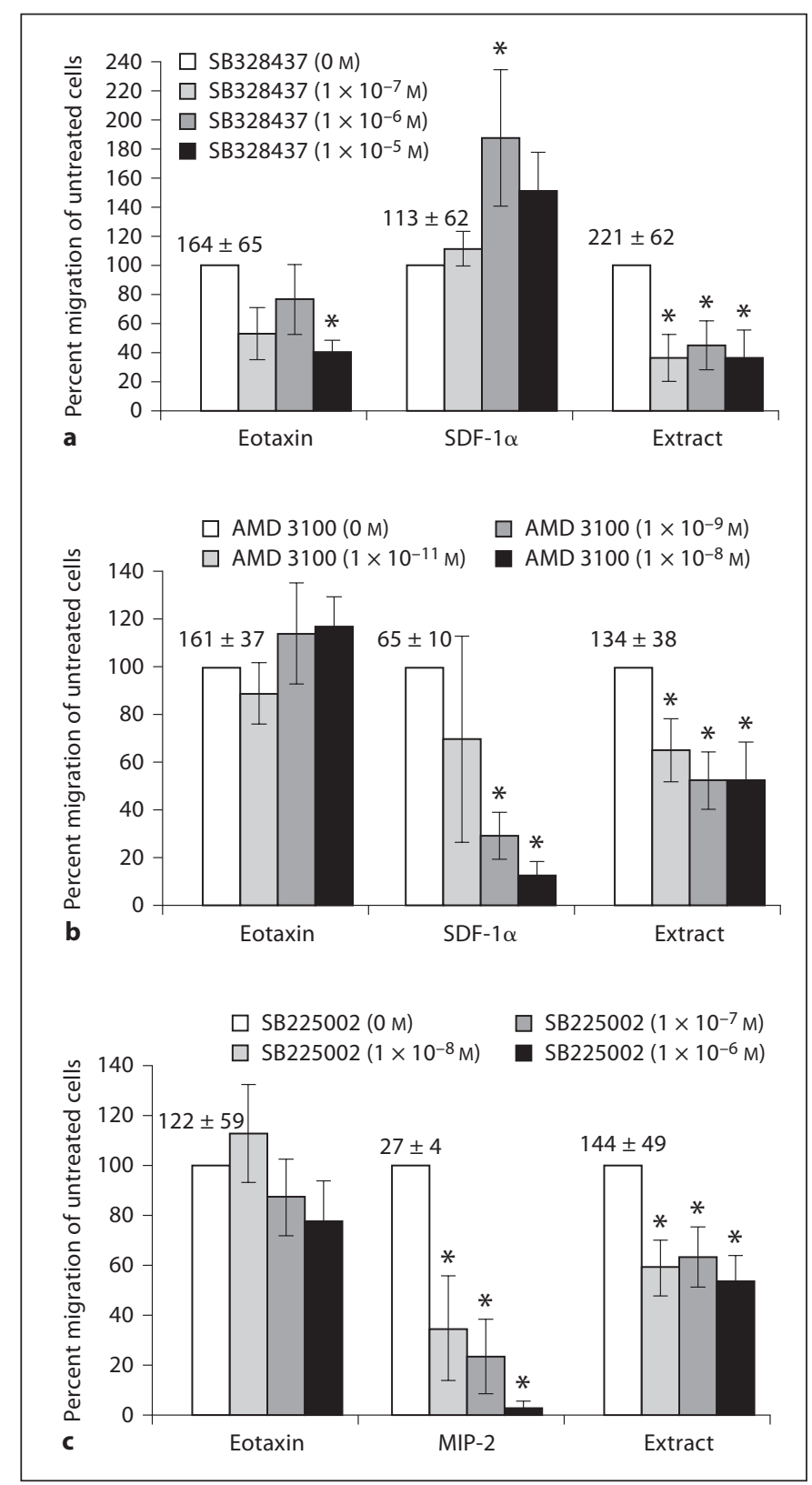

Fig. 4. Effect of blocking chemokine receptors on eosinophil migration in response to $S$. stercoralis soluble extract. Eosinophils $\left(1 \times 10^{6}\right)$ were added with IL-5 $(30 \mathrm{ng} / \mathrm{ml})$ to the upper chambers of a transwell plate. Chemotaxis was stimulated for $2 \mathrm{~h}$ with either eotaxin/CCL11 (80 ng/ml), SDF-1 $\alpha /$ CXCL12 (400 $\mu \mathrm{g} / \mathrm{ml})$, MIP2/CXCL2 $(100 \mathrm{ng} / \mathrm{ml})$ or $S$. stercoralis extract $(1 \mathrm{mg} / \mathrm{ml})$ in the lower wells. a Treatment with the CCR3 antagonist, SB328437. b Treatment with the CXCR4 antagonist, AMD3100. c Treatment with the CXCR2 antagonist, SB225002. Data are presented as percentage of migration in relation to untreated control, represented as $100 \%$. These data represent the mean percentage over 5-6 experiments \pm standard error of the mean. Numbers above control bars indicate the raw number of untreated migrated cells (arithmetic mean \pm standard error of the mean $\times 10^{3}$ migrated cells). ${ }^{*} \mathrm{p}<0.05$. tion to the parasite extract was inhibited in a similar dose-response fashion, with a maximal inhibition of $82 \%$. In contrast, blocking p38 with SB202190 did not significantly inhibit eosinophil chemotaxis in response to SDF$1 \alpha /$ CXCL12 (fig. 3a).

Eosinophils were pretreated with PD98059 to determine the role of $\mathrm{p} 42 / 44$ signaling in extract-induced chemotaxis. Migration to eotaxin/CCL11, SDF-1 $\alpha /$ CXCL12 and the parasite extract were significantly inhibited in a dose-response manner at all concentrations of PD98059. Maximal inhibition of eosinophil chemotaxis to eotaxin/ CCL11 was 97\%, to SDF-1 $\alpha /$ CXCL12 $65 \%$ and to the parasite extract $74 \%$ (fig. 3b). These data demonstrate that eosinophil chemotaxis to the parasite extract requires both p38 and p42/44 MAPK like with eotaxin/CCL11, while SDF- $1 \alpha /$ CXCL12 stimulation uses only p42/44.

\section{Blocking Specific Chemokine Receptors Inhibits}

Eosinophil Chemotaxis in Response to S. stercoralis

Soluble Extract

Chemokine receptor antagonists were used to block specific PTX-sensitive GPCR. CCR3 has been shown to have a dominant effect on directing eosinophil chemotaxis [23]. Treatment with the CCR3 antagonist, SB328437, was used to determine its role in extract-activated chemotaxis. Eosinophil migration to eotaxin/CCL11 was significantly inhibited by $60 \%$ only at the highest tested dose of SB328437. This antagonist significantly inhibited eosinophil chemotaxis in response to the parasite extract at all tested doses, with a maximum $64 \%$ reduction of migration compared to untreated cells. The CCR3 antagonist did not inhibit eosinophil migration provoked by SDF- $1 \alpha /$ CXCL12 at any dose. On the contrary, there was a significant $87 \%$ increase in migration caused by SDF-1 $\alpha /$ CXCL12 with eosinophils pretreated with $1 \times$ $10^{-6} \mathrm{M}$ of inhibitor (fig. 4a).

CXCR4 is an important mediator in directing migration of several granulocytes, including eosinophils, during various states of inflammation [26]. Eosinophils were treated with the antagonist AMD3100 to block CXCR4. The 2 highest tested doses of AMD3100 significantly inhibited eosinophil migration produced by SDF-1 $\alpha /$ CXCL12 by $87 \%$. Eosinophil migration activated by the parasite extract was also significantly inhibited by $47 \%$ at the same doses of inhibitor. Predictably, inhibition of CXCR4 had no effect on eosinophil chemotaxis to eotaxin/CCL11 (fig. 4b).

The CXCR2 antagonist, SB225002, was used to ascertain whether the parasite extract stimulates eosinophil migration through this receptor. SB225002 significantly 
Fig. 5. Characterization of the biochemical properties of the chemotactic components of $S$. stercoralis extract. a Fractionated concentrates, adjusted to equal total protein concentrations, were added to the lower well of transwell plates. b To determine the chemical nature of molecules responsible for eosinophil chemotaxis, the extract was pretreated with either proteinase $\mathrm{K}$, a nonspecific protease, chitinase or boiling at $100^{\circ} \mathrm{C}$ for $10 \mathrm{~min}$. Data are presented as the percentage of migration in relation to untreated control, represented as $100 \%$. Bars represent the mean percentage over 5-6 experiments \pm standard error of the mean. Numbers above control bars indicate the raw number of untreated migrated cells (arithmetic mean \pm standard error of the mean $\times 10^{3}$ migrated cells). ${ }^{*} \mathrm{p}<0.05$.

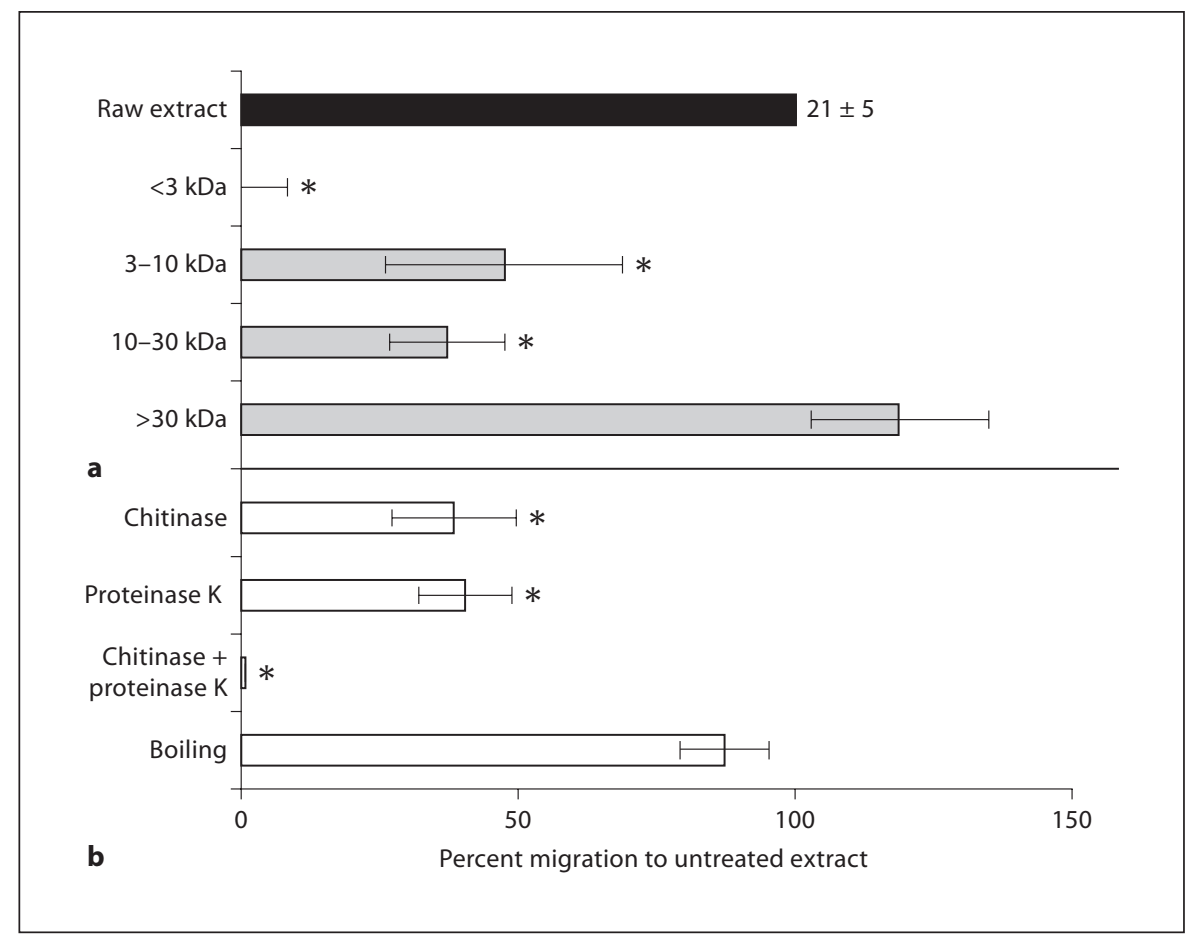

inhibited eosinophil migration to MIP-2/CXCL2 in a dose-dependent fashion, with a maximum $97 \%$ inhibition of baseline chemotaxis. Migration produced by eotaxin/CCL11 stimulation was not affected by SB225002; however, chemotaxis triggered by the $S$. stercoralis extract was significantly inhibited by SB225002 by $46 \%$ at all doses tested (fig. 4c).

We then confirmed that the inhibition observed in these experiments is not secondary to a nonspecific process associated with the antagonists used. To do this, we evaluated the effect of pretreatment with an antagonist, chemically similar to those used, to the NK3 receptor (SB222200). NK3 has been shown to have a negligible role in eosinophil migration [40]. Pretreatment with SB22200 did not significantly effect eosinophil migration to eotaxin/CCL11 or the extract ( $\mathrm{n}=5$; data not shown). Therefore, the inhibition in the CCR3, CXCR2 and CXCR4 experiments is due to specific receptor blocking rather than nonspecific effects of the antagonist.

\section{Characterization of the Biochemical Properties of the}

Chemotactic Components of S. stercoralis Extract

$S$. stercoralis extract was separated into fractions containing molecules $<3 \mathrm{kDa}, 3-10 \mathrm{kDa}, 10-30 \mathrm{kDa}$ and $>30$ $\mathrm{kDa}$. Concentration of each fraction was normalized to $1 \mathrm{mg} / \mathrm{ml}$ and the effect of fractionation was calculated as the percent of eosinophil migration to a given fraction as a percent of migration to the unfractionated extract. Extract components in the $3-$ to $30-\mathrm{kDa}$ molecular weight range induced significant eosinophil migration; although, this was significantly (60\%) less than that stimulated by the unfractionated extract. In contrast, migration to the fraction containing molecules greater than or equal to $30 \mathrm{kDa}$ was slightly, but not significantly, greater than migration to the whole extract (fig. 5a).

Parasite extract was pretreated with proteinase K, chitinase or boiling to ascertain the biochemical nature of the molecules responsible for eosinophil chemotaxis. Neither proteinase K nor chitinase alone induced eosinophil chemotaxis (data not shown). Pretreatment of the extract with proteinase $\mathrm{K}$ or chitinase significantly inhibited eosinophil chemotaxis by approximately $61 \%$. Treatment with both proteinase $\mathrm{K}$ and chitinase resulted in the complete inhibition of eosinophil chemotaxis to the parasite extract. Boiling did not significantly affect the chemotactic activity of the extract (fig. 5b). Therefore, eosinophil migration to extract from S. stercoralis is due to heat-stable protein and chitin components which are predominantly but not exclusively above 30 $\mathrm{kDa}$ in size. 


\section{Discussion}

The goal of these studies was to determine if a soluble extract of larval S. stercoralis would induce eosinophil migration and to define the mechanism by which this migration occurs. S. stercoralis extract activated several intracellular second messenger signal pathways stimulated by mammalian chemokines. The parasite extract activated eosinophil migration by stimulating a surprising diversity of chemokine receptors expressed in eosinophils. Furthermore, the chemotactic factors derived from the nematode were composed of either protein or chitin and were heat stable, with the most potent components of this extract greater than $30 \mathrm{kDa}$ in size.

LPS, which has been shown to generate eosinophil chemotaxis by stimulating the CCR3 receptor [41], was detected in the extract samples. However, concentrations of LPS 10 -fold above and below that found in the extract failed to induce eosinophil migration in our assays. Pretreatment of the extract with polymyxin $B$, known to form complexes with LPS lipid A [42], did not affect eosinophil migration in response to the extract. In contrast, treatment of the extract with a nonspecific protease or chitinase inhibited eosinophil migration, further suggesting migration of the eosinophils was not the result of LPS, but rather a response to parasite-derived materials.

Leukocyte migration occurs in either a directed (chemotactic) or a random (chemokinetic) fashion. ZigmondHirsch checkerboard analysis demonstrated that the parasite extract stimulates both eosinophil chemotaxis and chemokinesis. Maximum chemokinetic activation was, however, $56 \%$ of the chemotactic effect. The chemokinesis observed in this study may be partially due to the incubation of eosinophils with IL-5, which potentiates eosinophil actin polymerization after chemokine stimulation [43] and induction of chemokinesis [44], in the upper wells of the transwell plates. IL-5 is a normal component of the eosinophil milieu and it was added to the assays based on reports that it primes eosinophils to respond to host chemokines $[45,46]$, and may therefore be needed for eosinophils to respond optimally to the parasite extract. These studies show that eosinophils receive signals for chemotaxis directly from the worm, thereby potentiating innate and adaptive immunity to $S$. stercoralis.

To better understand how nematode-derived chemoattractants attract eosinophils, the second messenger signals responsible for inducing chemotaxis by nematode-derived products were investigated. Eosinophil chemotaxis in response to either eotaxin/CCL11 or S. stercoralis extract was substantially inhibited $(>80 \%)$ by treat- ing the cells with PTX. Thus, the extract stimulates eosinophil migration predominantly through $\mathrm{G} \alpha_{i}$ GPCR. This pathway is utilized not only by mammalian chemokines involved in the atopic response [47], but also by parasite-derived chemotactic molecules [16]. Chemokines induce migration by stimulating PTX-sensitive GPCR [48], while chemokinetic factors utilize cell surface receptors which exist as dimers $[44,49,50]$. Taken together, these data distinguish eosinophil migration to the parasite extract as a chemotactic-dependent migration of the cells.

While chemokines ubiquitously stimulate $\mathrm{G} \alpha_{\mathrm{i}} \mathrm{GPCR}$, different second messenger signals are involved in the intracellular signaling of various chemokine receptors [51, $52]$. It has been reported that $\alpha$ - and $\beta$-chemokines could stimulate different second messenger pathways [53-55]. Therefore, we compared the intracellular signaling of the $S$. stercoralis extract to that of the $\alpha$-chemokine SDF- $1 \alpha /$ CXCL12 and the $\beta$-chemokine eotaxin/CCL11. Both $\alpha$ and $\beta$-chemokines stimulate PI3K, which participates in pseudopod extension and F-actin organization in neutrophils undergoing chemotaxis. A potent nonspecific inhibitor of PI3K, wortmannin, was used to evaluate the relative role of PI3K in extract-induced chemotaxis. Preincubation of eosinophils with wortmannin inhibited $>90 \%$ of chemotaxis in response to eotaxin/CCL11, SDF$1 \alpha /$ CXCL12 and the parasite extract. Preincubating eosinophils from atopic patients with wortmannin inhibits eosinophil chemotaxis in response to eotaxin/CCL11 by approximately $60 \%$ and to platelet-activating factor by $85 \%$ [51]. These data demonstrate that PI3K mediates signaling of eosinophil chemotaxis by mammalian $\alpha$ - and $\beta$-chemokines as well as parasite-derived extract.

Chemokine receptors employ tyrosine kinase stimulation to varying degrees. The present study demonstrates that the tyrosine kinase inhibitor herbimycin A inhibited eosinophil chemotaxis in response to eotaxin/CCL11, SDF- $1 \alpha / C X C L 12$ and the extract. The magnitude of herbimycin A inhibition of eotaxin/CCL11 was greater than that observed with SDF-1 $\alpha /$ CXCL12 and identical to the inhibition of chemotaxis stimulated by the $S$. stercoralis extract. Previous reports demonstrate that preincubation of eosinophils with herbimycin A inhibited migration in response to eotaxin/CCL11 but not platelet-activating factor [52]. The limited inhibition by herbimycin $\mathrm{A}$ in the present study suggests that tyrosine kinases play an ancillary role in stimulating eosinophil chemotaxis. Therefore, the early steps of parasite-induced migration involve stimulation of a PTX-sensitive surface GPCR, which subsequently activates both a class $1 \mathrm{~B}$ PI3K variant through 


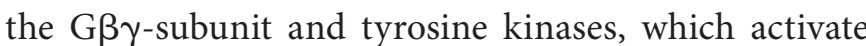
class $1 \mathrm{~A}$ PI3K.

MAPK signaling is highly conserved among phyla and can integrate multiple signaling cascades [56]. Eosinophil chemotaxis triggered by eotaxin/CCL11 is significantly $(>90 \%)$ inhibited by either the p38 inhibitor SB202190 or the p44 inhibitor PD98059, suggesting both kinases play a significant role in eotaxin/CCL11-induced chemotaxis [30]. Our data confirm previous findings that SDF-1 $\alpha /$ CXCL12 mediates signaling through a p44/42 pathway and not through p38 [33], unlike eotaxin/CCL11 which uses both MAP kinases. This has led some authors to hypothesize a differential use of p44/42 and p38 by $\alpha$ - and $\beta$-chemokines [33]. Blocking p38 or p44 significantly inhibited eosinophil migration to the $S$. stercoralis extract. However, it was not inhibited in the same magnitude as eotaxin/CCL11. Because the second messenger signals used by the $S$. stercoralis extract do not allow their functional categorization as either $\alpha$ - or $\beta$-chemokines, selective antagonists were used to determine the type of receptor utilized by $S$. stercoralis extract.

Eosinophils express multiple PTX-sensitive chemokine receptors which utilize the mammalian signaling pathways. A cross-section of chemokine receptors was selected to determine which receptors mediate the chemotaxis induced by $S$. stercoralis. The antagonists used to block the $\beta$-chemokine receptor CCR 3 and the $\alpha$-chemokine receptors CXCR2 and CXCR4 demonstrated specific blocking of chemotaxis in response to each receptor's control ligand. The specific SDF-1 $\alpha /$ CXCL12 stimulation of CXCR4 and MIP-2/CXCL2 stimulation of CXCR2 were both inhibited by $>90 \%$; however, these same antagonists blocked S. stercoralis extract by $52-54 \%$. The CCR3 antagonist blocked both eotaxin/CCL11- and extract-induced migration by approximately $60 \%$. The disparity in the magnitude of inhibition between receptors is likely due to specific characteristics of the antagonist. The antagonists for both CCR3 and CXCR4 were originally generated against the human forms of the receptors [57-59]. There is $91 \%$ homology between mouse and human CXCR4 [60], whereas there is $63 \%$ homology between mouse and human CCR3 [61, 62] which might explain the reduced activity of the CCR3 antagonist compared to the CXCR4 antagonist. Because the tested antagonists are unable to inhibit eosinophil migration to the extract in the same magnitude as for pure agonists, we conclude the $S$. stercoralis extract stimulates multiple chemokine receptors. This conclusion is supported by the observation that the eosinophil response to $S$. stercoralis was preserved in CXCR2 knockout mice [7]. Thus, a re- dundancy in stimulating eosinophil migration may serve as a protective advantage in responding to nematode infections. In contrast, while multiple chemokines have been implicated in diseases related to atopy, the CCR3 receptor appears to dominate control of eosinophil migration [63]. This is illustrated by the fact that blocking CCR3 results in the ablation of eosinophil recruitment and subsequent tissue dysfunction in response to antigen $[25,64,65]$.

The chemoattractants derived from S. stercoralis demonstrated remarkable biochemical heterogeneity. Approximately 50 chemokines, all proteins between 5 and $20 \mathrm{kDa}$ MW, have been identified in humans $[1,66]$. Some nematodes release chemoattractant molecules identical to those found in mammals [17]. Other chemotactic molecules isolated from nematodes have biochemical properties distinct from mammalian chemokines, including a nonprotein biochemistry [18] and larger molecular weight $[16,67,68]$. Chitin has also been associated with the recruitment of eosinophils to a nematode infection through a mechanism dependent on macrophages [69]. The observation that only eosinophils underwent chemotaxis to the parasite extract in the present study suggests that eosinophils respond to chitin from S. stercoralis in a macrophage-independent manner. In the present study, fractions of the S. stercoralis extract with molecular weights greater than $30 \mathrm{kDa}$ were the most effective in stimulating eosinophil migration. Fractions in the 3 - to $30-\mathrm{kDa}$ molecular weight range also caused significant eosinophil migration above control. However, this was significantly (60\%) less than that stimulated by the unfractionated extract. Although total protein concentration was standardized to $1 \mathrm{mg} / \mathrm{ml}$ in each fraction, there was likely an increase in the relative concentration of the active chemotactic elements in the $>30-\mathrm{kDa}$ fraction accounting for the slight increase in chemotaxis. Although the majority of chemotactic activity observed in response to the $S$. stercoralis extract is due to molecules greater than $30 \mathrm{kDa}$, it is reasonable to conclude that chemotaxis is due to multiple active components of various sizes within the extract. Treatment of the parasite extract with either chitinase or proteinase $\mathrm{K}$ inhibited the extract's ability to attract eosinophils. Simultaneous treatment with both enzymes completely blocked eosinophil migration to the extract. Therefore, eosinophils are attracted to molecules of various sizes within the $S$. stercoralis extract which are either protein or chitin in nature.

Polyspeirism, multiple chemokines recognized by 1 cell type, has been described for monocytes. This allows the cells to respond to diverse stimuli using varied CC, 
CX3C and CXC receptors, thereby ensuring a robust immune response [70]. Based on the current study, eosinophils also appear to express polyspeirism in the response to infection with $S$. stercoralis. This guarantees that eosinophils are recruited to the parasites during the innate immune response without the need for other cell's production of chemokines. Eosinophils have been shown to have the capacity to kill the parasites in the innate immune response [7] and act as antigen-presenting cells $[71,72]$, thereby initiating the adaptive immune response. Eosinophil polyspeirism promotes the ability of eosinophils to function as killing cells in the innate immune response and as transition cells to the adaptive immune response. Alternatively, it has been observed that in the absence of eosinophils, $T$. spiralis muscle larvae died in large numbers [73]. This suggests that eosinophils may influence the immune response in a manner that insures worm survival. If eosinophils also promote the survival of S. stercoralis, there might be a selective advantage for the parasite to directly recruit the cells.
In conclusion, our data demonstrate a soluble extract from S. stercoralis stimulates eosinophil chemotaxis by binding to multiple GPCR chemokine receptors on the eosinophil and triggering second messenger signal pathways parallel to those induced by mammalian chemokines. The chemotactic components of the extract are complex and biochemically different from mammalian chemokines. The redundancy of the chemotactic factors produced by the parasite and the multiple responding receptors on the eosinophils suggest that chemotactic receptors on these pivotal cells may have evolved to ensure a robust response to this infection.

\section{Acknowledgments}

This work was supported by NIH grants RO1 AI47189, RO1 A1 22662 and R01 AI 50668 as well as the Mayo Foundation. The authors wish to thank Jessica Hess, Amy O'Connell and Udai Padigel for their expert and enthusiastic technical assistance.

\section{References}

1 Gerard C, Rollins BJ: Chemokines and disease. Nat Immunol 2001;2:108-115.

$\checkmark 2$ Luster AD: Chemokines - chemotactic cytokines that mediate inflammation. $\mathrm{N}$ Engl J Med 1998;338:436-445.

- 3 Mir A, Benahmed D, Igual R, Borras R, O'Connor JE, Moreno MJ, et al: Eosinophilselective mediators in human strongyloidiasis. Parasite Immunol 2006;28:397-400.

4 Klion AD, Nutman TB: The role of eosinophils in host defense against helminth parasites. J Allergy Clin Immunol 2004;113:3037.

5 Ramalingam T, Porte P, Lee J, Rajan TV: Eosinophils, but not eosinophil peroxidase or major basic protein, are important for host protection in experimental Brugia pahangi infection. Infect Immun 2005;73:84428443

-6 Abraham D, Leon O, Schnyder-Candrian S, Wang CC, Galioto AM, Kerepesi LA, et al: Immunoglobulin $\mathrm{E}$ and eosinophil-dependent protective immunity to larval Onchocerca volvulus in mice immunized with irradiated larvae. Infect Immun 2004;72: 810-817.

-7 Galioto AM, Hess JA, Nolan TJ, Schad GA, Lee JJ, Abraham D: Role of eosinophils and neutrophils in innate and adaptive protective immunity to larval Strongyloides stercoralis in mice. Infect Immun 2006;74:57305738.
-8 Pearlman E, Toe L, Boatin BA, Gilles AA, Higgins AW, Unnasch TR: Eotaxin expression in Onchocerca volvulus-induced dermatitis after topical application of diethylcarbamazine. J Infect Dis 1999;180:1394-1397.

-9 Cooper PJ, Beck LA, Espinel I, Deyampert NM, Hartnell A, Jose PJ, et al: Eotaxin and RANTES expression by the dermal endothelium is associated with eosinophil infiltration after ivermectin treatment of onchocerciasis. Clin Immunol 2000;95:51-61.

-10 Simons JE, Rothenberg ME, Lawrence RA: Eotaxin-1-regulated eosinophils have a critical role in innate immunity against experimental Brugia malayi infection. Eur J Immunol 2005;35:189-197.

11 Dixon H, Blanchard C, Deschoolmeester ML, Yuill NC, Christie JW, Rothenberg ME, et al: The role of Th2 cytokines, chemokines and parasite products in eosinophil recruitment to the gastrointestinal mucosa during helminth infection. Eur J Immunol 2006;36: 1753-1763.

12 Wildblood LA, Kerr K, Clark DA, Cameron A, Turner DG, Jones DG: Production of eosinophil chemoattractant activity by ovine gastrointestinal nematodes. Vet Immunol Immunopathol 2005;107:57-65.

13 Tanaka J, Torisu M: Anisakis and eosinophil. I. Detection of a soluble factor selectively chemotactic for eosinophils in the extract from Anisakis larvae. J Immunol 1978;120: 745-749.
14 Owhashi M, Ishii A: Purification and characterization of a high molecular weight eosinophil chemotactic factor from Schistosoma japonicum eggs. J Immunol 1982;129: 2226-2231.

15 Niwa A, Miyazato T: Enhancement of intestinal eosinophilia during Hymenolepis nana infection in mice. J Helminthol 1996;70:3341.

16 Ramirez BL, Howard OM, Dong HF, Edamatsu T, Gao P, Hartlein M, et al: Brugia malayi asparaginyl-transfer RNA synthetase induces chemotaxis of human leukocytes and activates G-protein-coupled receptors CXCR1 and CXCR2. J Infect Dis 2006;193: 1164-1171

- 17 Massey HC, Castelletto ML, Bhopale VM, Schad GA, Lok JB: Sst-tgh-1 from Strongyloides stercoralis encodes a proposed ortholog of daf-7 in Caenorhabditis elegans. Mol Biochem Parasitol 2005;142:116-120.

18 Tsuda S, Fukuyama K, Epstein WL: Low molecular weight eosinophil chemotactic factor in granulomatous liver of murine schistosomiasis. J Immunol 1979;122:2554-2557.

19 Prossnitz ER, Ye RD: The N-formyl peptide receptor: a model for the study of chemoattractant receptor structure and function. Pharmacol Ther 1997;74:73-102.

20 Devreotes PN, Zigmond SH: Chemotaxis in eukaryotic cells - a focus on leukocytes and dictyostelium. Ann Rev Cell Biol 1988;4: 649-686. 
21 Thelen M: Dancing to the tune of chemokines. Nat Immunol 2001;2:129-134.

22 Daugherty BL, Siciliano SJ, DeMartino JA, Malkowitz L, Sirotina A, Springer MS: Cloning, expression, and characterization of the human eosinophil eotaxin receptor. J Exp Med 1996;183:2349-2354.

-23 Heath H, Qin S, Rao P, Wu L, LaRosa G, Kassam N, et al: Chemokine receptor usage by human eosinophils. The importance of CCR3 demonstrated using an antagonistic monoclonal antibody. J Clin Invest 1997;99: 178-184.

24 Fujisawa T, Kato Y, Nagase H, Atsuta J, Terada A, Iguchi K, et al: Chemokines induce eosinophil degranulation through CCR-3. J Allergy Clin Immunol 2000;106:507-513.

$\checkmark 25$ Ma WBP, Humbles AA, Laouini D, Yalcindag A, Alenius H, Friend DS, Oettgen HC, Gerard C, Geha RS: CCR3 is essential for skin eosinophilia and airway hyperresponsiveness in a murine model of allergic skin inflammation. J Clin Invest 2002;109: 621-628.

-26 Nagase H, Kudo K, Izumi S, Ohta K, Kobayashi N, Yamaguchi M, et al: Chemokine receptor expression profile of eosinophils at inflamed tissue sites: decreased CCR3 and increased CXCR4 expression by lung eosinophils. J Allergy Clin Immunol 2001;108:563569.

27 Ben-Baruch A, Michiel DF, Oppenheim JJ: Signals and receptors involved in recruitment of inflammatory cells J Biol Chem 1995;270:11703-11706.

28 Wong WS: Inhibitors of the tyrosine kinase signaling cascade for asthma. Curr Opin Pharmacol 2005;5:264-271.

29 Johnson GL, Lapadat R: Mitogen-activated protein kinase pathways mediated by ERK, JNK, and p38 protein kinases. Science 2002; 298:1911-1912.

- 30 Kampen GT, Stafford S, Adachi T, Jinquan T, Quan S, Grant JA, et al: Eotaxin induces degranulation and chemotaxis of eosinophils through the activation of ERK2 and p38 mitogen-activated protein kinases. Blood 2000; 95:1911-1917.

- 31 Boehme SA, Sullivan SK, Crowe PD, Santos $\mathrm{M}$, Conlon PJ, Sriramarao P, et al: Activation of mitogen-activated protein kinase regulates eotaxin-induced eosinophil migration. J Immunol 1999;163:1611-1618.

- 32 Terakawa M, Tomimori Y, Goto M, Hayashi Y, Oikawa S, Fukuda Y: Eosinophil migration induced by mast cell chymase is mediated by extracellular signal-regulated kinase pathway. Biochem Biophys Res Commun 2005;332:969-975.

- 33 Ganju RK, Brubaker SA, Meyer J, Dutt P, Yang Y, Qin S, et al: The $\alpha$-chemokine, stromal cell-derived factor- $1 \alpha$, binds to the transmembrane G-protein-coupled CXCR-4 receptor and activates multiple signal transduction pathways. J Biol Chem 1998;273: 23169-23175.
- 34 Holub A, Byrnes J, Anderson S, Dzaidzio L, Hogg N, Huttenlocher A: Ligand density modulates eosinophil signaling and migration. J Leukoc Biol 2003;73:657-664.

- 35 Lee JJ, McGarry MP, Farmer SC, Denzler KL, Larson KA, Carrigan PE, et al: Interleukin-5 expression in the lung epithelium of transgenic mice leads to pulmonary changes pathognomonic of asthma. J Exp Med 1997; 185:2143-2156.

36 Abraham D, Rotman HL, Haberstroh HF, Yutanawiboonchai W, Brigandi RA, Leon O, et al: Strongyloides stercoralis: protective immunity to third-stage larvae inBALB/cByJ mice. Exp Parasitol 1995;80:297-307.

- 37 Borchers MT, Ansay T, DeSalle R, Daugherty BL, Shen H, Metzger M, et al: In vitro assessment of chemokine receptor-ligand interactions mediating mouse eosinophil migration. J Leukoc Biol 2002;71:1033-1041.

38 Pero RS, Borchers MT, Spicher K, Ochkur SI, Sikora L, Rao SP, et al: Goi2-mediated signaling events in the endothelium are in volved in controlling leukocyte extravasation. Proc Natl Acad Sci USA 2007;104: 4371-4376.

39 Zigmond SH, Hirsch JG: Leukocyte locomotion and chemotaxis. New methods for evaluation, and demonstration of a cell-derived chemotactic factor. J Exp Med 1973;137:387410.

40 Kung TT, Crawley Y, Jones H, Luo B, Gilchrest $\mathrm{H}$, Greenfeder S, et al: Tachykinin NK3receptor deficiency does not inhibit pulmonaryeosinophilia in allergic mice. Pharmacol Res 2004;50:611-615.

41 Penido C, Castro-Faria-Neto HC, Vieira-deAbreu A, Figueiredo RT, Pelled A, Martins MA, et al: LPS induces eosinophil migration via CCR3 signaling through a mechanism independent of RANTES and Eotaxin. Am J Respir Cell Mol Biol 2001;25:707-716.

-42 Vaara M, Vaara T, Jensen M, Helander I, Nurminen M, Rietschel ET, et al: Characterization of the lipopolysaccharide from the polymyxin-resistant pmrA mutants of Salmonella typhimurium. FEBS Lett 1981;129: 145-149.

43 Kaatz M, Berod L, Czech W, Idzko M, Lagadari M, Bauer A, et al: Interleukin-5, interleukin-3 and granulocyte-macrophage colony-stimulating factor prime actin-polymerization in human eosinophils: a study with hypodense and normodense eosinophils from patients with atopic dermatitis. Int J Mol Med 2004;14:1055-1060.

44 Schweizer RC, van Kessel-Welmers BA, Warringa RA, Maikoe T, Raaijmakers JA, Lammers JW, et al: Mechanisms involved in eosinophil migration. Platelet-activating factor-induced chemotaxis and interleukin-5induced chemokinesis are mediated by different signals. J Leukoc Biol 1996;59:347-356.
45 Rothenberg ME, Ownbey R, Mehlhop PD, Loiselle PM, van de Rijn M, Bonventre JV, et al: Eotaxin triggers eosinophil-selective chemotaxis and calcium flux via a distinct receptor and induces pulmonary eosinophilia in the presence of interleukin 5 in mice. Mol Med 1996;2:334-348.

46 Shahabuddin S, Ponath P, Schleimer RP: Migration of eosinophils across endothelial cell monolayers: interactions among IL-5, endothelial-activating cytokines, and $\mathrm{C}-\mathrm{C}$ chemokines. J Immunol 2000;164:3847-3854.

47 Gangur V, Oppenheim JJ: Are chemokines essential or secondary participants in allergic responses? Ann Allergy Asthma Immunol 2000;84:569-79; quiz 579-581.

48 Bischoff SC, Krieger M, Brunner T, Rot A, von Tscharner V, Baggiolini M, et al: RANTES and related chemokines activate human basophil granulocytes through different $G$ protein-coupled receptors. Eur J Immunol 1993;23:761-767.

49 Ishino T, Robertson N, Chaiken I: Cytokine recognition by human interleukin 5 receptor. Vitam Horm 2005;71:321-344.

-50 Miyajima A, Kitamura T, Harada N, Yokota T, Arai K: Cytokine receptors and signal transduction. Annu Rev Immunol 1992;10: 295-331.

51 Mishra RK, Scaife JE, Harb Z, Gray BC, Djukanovic R, Dent G: Differential dependence of eosinophil chemotactic responses on phosphoinositide 3-kinase (PI3K). Allergy 2005;60:1204-1207.

52 El-Shazly A, Masuyama K, Samejima Y, Eura $\mathrm{M}$, Ishikawa T: Modulation of normal human eosinophil chemotaxis in vitro by herbimycin A, erbstatin and pervanadate. Int Arch Allergy Immunol 1998; 117(suppl 1):1013.

53 Eberle M, Traynor-Kaplan AE, Sklar LA, Norgauer J: Is there a relationship between phosphatidylinositol trisphosphate and Factin polymerization in human neutrophils? J Biol Chem 1990;265:16725-16728.

54 Curnock AP, Logan MK, Ward SG: Chemokine signalling: pivoting around multiple phosphoinositide 3-kinases. Immunology 2002;105:125-136.

55 Zhelev DV, Alteraifi A: Signaling in the motility responses of the human neutrophil. Ann Biomed Eng 2002;30:356-370.

56 Pelaia G, Cuda G, Vatrella A, Gallelli L, Caraglia M, Marra M, et al: Mitogen-activated protein kinases and asthma. J Cell Physiol 2005;202:642-653.

57 De Clercq E: Inhibition of HIV infection by bicyclams, highly potent and specific CXCR4 antagonists. Mol Pharmacol 2000;57:833839.

58 De Clercq E, Yamamoto N, Pauwels R, Balzarini J, Witvrouw M, De Vreese K, et al: Highly potent and selective inhibition of human immunodeficiency virus by the bicyclam derivative JM3100. Antimicrob Agents Chemother 1994;38:668-674. 
59 White JR, Lee JM, Dede K, Imburgia CS, Jurewicz AJ, Chan $\mathrm{G}$, et al: Identification of potent, selective non-peptide CC chemokine receptor-3 antagonist that inhibits eotaxin-, eotaxin-2-, and monocyte chemotactic protein-4-induced eosinophil migration. J Biol Chem 2000;275:36626-36631.

-60 Schabath R, Muller G, Schubel A, Kremmer E, Lipp M, Forster R: The murine chemokine receptor CXCR4 is tightly regulated during $\mathrm{T}$ cell development and activation. J Leukoc Biol 1999;66:996-1004.

-61 Combadiere C, Ahuja SK, Murphy PM: Cloning and functional expression of a human eosinophil CC chemokine receptor. J Biol Chem 1995;270:16491-16494.

-62 Post TW, Bozic CR, Rothenberg ME, Luster AD, Gerard N, Gerard C: Molecular characterization of two murine eosinophil beta chemokine receptors. J Immunol 1995;155: 5299-5305.

-63 Pope SM, Zimmermann N, Stringer KF, Karow ML, Rothenberg ME: The eotaxin chemokines and CCR3 are fundamental regulators of allergen-induced pulmonary eosinophilia. J Immunol 2005;175:5341-5350.
64 Fryer AD, Stein LH, Nie Z, Curtis DE, Evans CM, Hodgson ST, et al: Neuronal eotaxin and the effects of CCR 3 antagonist on airway hyperreactivity and M2 receptor dysfunction. J Clin Invest 2006;116:228-236.

65 Nakamura T, Ohbayashi M, Toda M, Hall DA, Horgan CM, Ono SJ: A specific CCR3 chemokine receptor antagonist inhibits both early and late phase allergic inflammation in the conjunctiva. Immunol Res 2005;33:213221.

66 Van Coillie E, Van Damme J, Opdenakker G: The MCP/eotaxin subfamily of CC chemokines. Cytokine Growth Factor Rev 1999;10: 61-86.

67 Wadee AA, Sher R: The effects of a soluble factor released by sensitized mononuclear cells incubated with $S$. haematobium ova on eosinophil migration. Immunology 1980;41: 989-995.
68 Tanaka J, Baba T, Torisu M: Ascaris and eosinophil. II. Isolation and characterization of eosinophil chemotactic factor and neutrophil chemotactic factor of parasite in Ascaris antigen. J Immunol 1979;122:302-308.

69 Reese TA, Liang HE, Tager AM, Luster AD, Van Rooijen N, Voehringer D, et al: Chitin induces accumulation in tissue of innate immune cells associated with allergy. Nature 2007;447:92-96.

70 Mantovani A: The chemokine system: redundancy for robust outputs. Immunol Today 1999;20:254-257.

71 Padigel UM, Lee JJ, Nolan TJ, Schad GA, Abraham D: Eosinophils can function as antigen-presenting cells to induce primary and secondary immune responses to Strongyloides stercoralis. Infect Immun 2006;74:32323238.

72 Padigel UM, Hess JA, Lee JJ, Lok JB, Nolan TJ, Schad GA, et al: Eosinophils act as antigen presenting cells to induce immunity to Strongyloides stercoralis in mice. J Infect Dis 2007;196:1844-1851.

-73 Fabre V, Beiting DP, Bliss SK, Gebreselassie NG, Gagliardo LF, Lee NA, et al: Eosinophil deficiency compromises parasite survival in chronic nematode infection. J Immunol 2009;182:1577-1583. 